\title{
Do lesions of the enteric nervous system occur following intestinal ischemia/reperfusion? ${ }^{1}$
}

\author{
Ocorrem lesões do sistema nervoso entérico após \\ isquemia/reperfusão intestinal?
}

\author{
Glauber Kazuo Linhares², José Luiz Martins³, Fernanda Fontanezzi², Francy dos Reis Patrício ${ }^{4}$, Edna Frasson de \\ Souza Montero 5 \\ 1. Research performed at Pediatric Surgery and Operative Technique and Experimental Surgery Divisions, Federal University of São Paulo \\ (UNIFESP). São Paulo, Brazil. \\ 2. Graduate student, Faculty of Medicine, UNIFESP. São Paulo, Brazil \\ 3. Associate Professor, Division of Pediatric Surgery, Department of Surgery, UNIFESP. São Paulo, Brazil. \\ 4. Associate Professor, Division of Medical Pathology, Department of Pathology, UNIFESP. São Paulo, Brazil. \\ 5. Affiliate Professor, Division of Operative Technique and Experimental Surgery, Surgery Department of UNIFESP. São Paulo, Brazil.
}

\begin{abstract}
Purpose: To evaluate tissue lesions, especially those of the intestinal innervation, in an excluded jejunal loop subjected to ischemia and reperfusion in rats. Methods: To evaluate the role of ischemia and reperfusion lesions in an excluded intestinal loop, four groups of 20 rats were set up: control group (GCEI7) and three experimental groups (GIREI7, GIREI14 and GIREI28). They were all subjected to exclusion of an intestinal segment of six centimeters in length, at a distance of 10 centimeters from the Treitz angle. The 60 animals in the three experimental groups were additionally subjected to ischemia of the vascular pedicle for 30 minutes. The control group and the experimental group GIREI7 were evaluated on the $7^{\text {th }}$ day after the operation. The groups GIREI14 and GIREI28 (which also underwent ischemia) were utilized to evaluate the evolution of the lesion over time, on the $14^{\text {th }}$ and $28^{\text {th }}$ days after the operation, respectively. From the intestinal excluded loop, we take one ring of $0,5 \mathrm{~cm}$ distal and proximal, that were fixed in formaline $10 \%$ solution in order to do histological (HE) and immuno-hystochemial (PS-100) evaluation (enteric nervous system.) The distal loop was exteriorized in stoma and the proximal part closed with polipropilene 6-0. Results: It was observed a decrease in the number of ganglionic cells in the myenteric plexus in the group subjected to ischemia and reperfusion (GIREI7), in relation to the control group (GCEI7) at the $7^{\text {th }}$ post-operative day (Mann-Whitney test: $p=0.0173 *$. Comparing the numbers of ganglionic cells in the myenteric plexus before and after jejunal loop exclusion GCEI7 - (Wilcoxon test: $p=0.0577$ ). GIREI7 - Comparing the numbers of ganglionic cells in the myenteric plexus before and after ischemia $(* p=0.0399)$. Comparing the percentage variations in ganglionic cells in the myenteric plexus on the $7^{\text {th }}, 14^{\text {th }}$ and $28^{\text {th }}$ days after the procedure, in the groups GIREI7, GIREI14 and GIREI28, it was observed that there were no significant alterations. Kruskal-Wallis test: $p=0.6501$. Conclusion: There was a decrease in the number of ganglionic cells in the myenteric plexus due to ischemia and reperfusion that did not recover in the late post-operative period.
\end{abstract}

Key words: Intestine, small. Ischemia. Reperfusion. Enteric nervous system.

\section{RESUMO}

Objetivo: Avaliar lesões teciduais, especialmente aquelas da inervação intestinal em alça jejunal excluída submetida à isquemia e reperfusão em ratos. Métodos: Para avaliar o papel da isquemia e reperfusão nas lesões em uma alça intestinal exclusa, quatro grupos de 20 ratos foram criados: Grupo controle (GCE17) e 3 Grupos experimentais (GIRE!7, GIREI14) e GIREI28) Todos foram submetidos à exclusão de um segmento intestinal de seis centímetros de extensão, a 10 centímetros do ângulo de Treitz . Os 60 animais dos 3 grupos experimentais foram também submetidos a isquemia do pedículo vascular por 30 minutos.O grupo controle e o grupo experimental GIREI7 foram avaliados no $7^{\circ}$. Dia após a operação. Os grupos GIREI14 e GIREI28 também submetidos à isquemia, foram utilizados para avaliar a evolução da lesão com o passar do tempo, no $14^{\circ}$. e $28^{\circ}$. dias respectivamente. Do segmento intestinal excluído do trânsito, foi retirada uma amostra de $0,5 \mathrm{~cm}$ em cada extremidade, proximal e distal, as quais foram fixadas em solução de formol $10 \%$ para posterior avaliação histológica, com HE e imuno histoquímica pela proteína PS-100 para avaliação do sistema nervoso entérico. A luz distal da alça isolada foi estomizada e a proximal fechada com pontos de prolene 60 . Esses dados foram analisados estatisticamente. Resultados: Observamos uma diminuição do número de células ganglionares no plexo mioentérico do grupo submetido à isquemia e reperfusão (GIREI7) em relação ao grupo controle (GCEI7). MannWhitney: $p=0,0173^{*}$. Comparando a variação percentual das células ganglionares do plexo mioentérico no $7^{\circ}, 14^{\circ}$ e $28^{\circ}$ dia após procedimento nos grupos GIREI7, GIREI14 E GIREI28 observamos que não houve alterações significantes. Kruskal-Wallis $\mathrm{p}=0,6501$. Conclusão: Houve uma diminuição das células ganglionares nos plexos mioentéricos devido à isquemia e reperfusão, não havendo recuperação no período pós-operatório tardio.

Descritores: Intestino delgado. Isquemia. Reperfusão. Sistema nervoso entérico. 


\section{Introduction}

The phenomenon of ischemia/reperfusion has a fundamental role in many situations experienced by surgeons, anesthetists and intensive care specialists, such as peripheral vascular insufficiency, acute myocardial infarct, hypovolemic shock, mesenteric ischemia and transplantation. Many newborns suffer cardiac arrest and cerebral ischemia as a consequence of low intestinal flow with significant ischemia followed by reperfusion after a varying period of time. Different degrees of lesion result from such ischemia/reperfusion phenomena $(\mathrm{I} / \mathrm{R})$. It is believed that ischemia/reperfusion is important in the etiopathogenesis of neonatal necrotizing enterocolitis, which is the most common gastrointestinal emergency in neonatal intensive care units ${ }^{1}$. This condition may lead to large-extent resection of the intestine ${ }^{2}$. The children who survive such resections may develop the so-called short bowel syndrome. In addition to the mortality presented by this syndrome, its morbid effects ends up definitively compromising the child's weight-height development, with implications also for neuropsychomotor development. Even though the restoration of the blood flow to an organ presenting ischemia is essential for preventing irreversible cell damage, ischemia followed by reperfusion causes significant tissue lesions ${ }^{3}$. Several studies have shown that these lesions are basically caused at the moment of the reperfusion ${ }^{4}$. Reperfusion lesions, unlike ischemic lesions, may produce systemic alterations such that the reestablishment of the blood flow to an ischemic area may cause damage to the whole organism ${ }^{5}$. On the other hand, there have been reports that, after 30 minutes of ischemia, there are tissue lesions visible under an optical microscope that are potentially reversible ${ }^{6,7}$. The full or partial participation of free radicals in microvascular lesions has been demonstrated, along with their participation in parenchymatous cells of tissue subjected to ischemia, through the hypoxia-reoxygenation process ${ }^{8-11}$. There are still doubts whether vascular lesions would or would not be accompanied by lesions of the intrinsic nervous system of the intestine $^{11}$, especially with regard to the myenteric plexus (Auerbach) and submucous plexus (Meissner), with consequent modification of the intestinal motility. Lesions of the nervous system have been described following ischemia/ reperfusion ${ }^{12-14}$, and many substances have been studied with a view to diminishing or avoiding these ischemia/reperfusion lesions ${ }^{11,15-17}$. However, it is not fully known what the characteristics of enteric nervous system lesions are, how they occur, and whether such damage is total or causes alterations to cell populations in the intestinal ganglia. On the basis of these facts, it was decided to study tissue lesions, especially those of the intestinal innervation, in an excluded jejunal loop subjected to ischemia and reperfusion in rats.

\section{Methods}

Eighty adult male Wistar EPM-1 rats (Rattus norvegicus albinus), weighing between 250 and $350 \mathrm{~g}$, and aging around
100 days were utilized. They came from the Development Center for Experimental Models for Medicine and Biology of the Federal University of São Paulo. All the animals were acclimatized and kept in controlled conditions of light, temperature, and receiving standard food and water ad libitum. After being placed under a fasting regime for 24 hours in relation to solid food, all the rats were anesthetized with ketamine and xylazine, at doses of 60 and $10 \mathrm{mg} / \mathrm{kg}$ of body weight, respectively, and were subjected to exploratory laparotomy.

\section{Experimental design}

To evaluate the role of ischemia and reperfusion lesions in an excluded intestinal loop, four groups of 20 rats were set up: control group (GCEI7) and three experimental groups (GIREI7, GIREI14 and GIREI28). They were all subjected to exclusion of an intestinal segment of six centimeters in length, at a distance of 10 centimeters from the Treitz angle. The 60 animals in the three experimental groups were additionally subjected to ischemia of the vascular pedicle for 30 minutes. The control group and the experimental group GIREI7 were evaluated on the $7^{\text {th }}$ day after the operation. The groups GIREI14 and GIREI28 (which also underwent ischemia) were utilized to evaluate the evolution of the lesion over time, on the $14^{\text {th }}$ and $28^{\text {th }}$ days after the operation, respectively.

\section{Exclusion of the intestinal loop}

At a distance of ten centimeters distally from the duodenaljejunal junction, an intestinal loop of six centimeters in length was isolated. The intestinal passage was reconstructed by means of enteroenteral anastomosis in a single plane, utilizing prolene 6-0 thread. From the intestinal segment that was excluded from the passage, a sample of $0.5 \mathrm{~cm}$ in length was removed at each end (proximal and distal). These were fixed in a $10 \%$ formol solution for subsequent histological evaluation. The distal lumen of the loop that was isolated was stomatized and the proximal lumen was closed using prolene 6-0 stitches.

\section{Ischemia and reperfusion of the excluded loop}

The excluded segment was subjected to ischemia for thirty minutes in the groups GIREI7, GIREI14 and GIREI28, with clamping of these intestinal vascular pedicle. Twenty-four hours after the surgery, appropriate diet was introduced and the rats were kept in individual cages throughout the postoperative period.

\section{Second surgery and euthanasia}

Animals from groups GCEI7 (control) and GIREI7 underwent reoperation after 7 days, by means of exploratory laparotomy to assess and remove two rings of 0.5 centimeters in length from the isolated loop. The same procedure was done after 14 days and 28 days for groups GIREI14 and GIREI28, respectively. After the second surgical procedure, the rats in 
all groups were submitted to euthanasia under anesthesia by means of exsanguination.

\section{Histological analysis}

Following the surgical procedures, the intestinal rings removed during the first and second surgical procedures were sent for analysis to the Department of Pathological Anatomy of the Federal University of São Paulo. Histological evaluation was done by means of hematoxylin-eosin (HE) staining, and immunohistochemical evaluation was done by means of protein S-100. Protein S-100 is specific for nerve tissue and is detected in the Schwann cells surrounding the myelinated and nonmyelinated nerve fibers and in the satellite cells around the ganglion cells. It is a marker of the perineural elements of the nervous system, and can also be found in tumors of the nervous system. In this evaluation method, the ganglia stain brown and the ganglionic cells stain purple (negatively) ${ }^{18-22}$. The detection method utilized for protein S-100 was the one described by Rocha in $2001^{21,22}$. Counts of the following were conducted for all groups in relation to both surgeries (in high magnification fields $-400 \mathrm{x}$ ): neural ganglia in the myenteric plexus and submucous plexus; and ganglionic cells in the myenteric plexus.

\section{Statistical analysis}

Non-parametric tests were utilized for the data analysis, taking into consideration the nature of the variables. To compare the variables analyzed at the pre and post-procedure times for each group separately, the Wilcoxon test was utilized. To compare the percentage variations $[\ddot{\mathrm{A}} \%=($ post - pre $) /$ pre $X$ 100] in the numbers of ganglionic cells in the myenteric plexus on the $7^{\text {th }}$ day after the procedure for the groups GCEI7 and GIREI7, the Mann-Whitney test was utilized. To compare the percentage variation in the ganglionic cells of the myenteric plexus on the $7^{\text {th }}, 14^{\text {th }}$ and $28^{\text {th }}$ days after the procedure for the groups GIREI7, GIREI14 and GIREI28, the Kruskal-Wallis test was utilized.

\section{Results}

It was observed a decrease in the number of ganglionic cells in the myenteric plexus in the group subjected to ischemia and reperfusion (GIREI7), in relation to the control group (GCEI7) at the $7^{\text {th }}$ post-operative day (Mann-Whitney test: $\mathrm{p}=$ $0.0173 *$ - Table 1 - Figure 1). Comparing the numbers of ganglionic cells in the myenteric plexus before and after jejunal loop exclusion (GCEI7 - Wilcoxon test: $p=0.0577$ ) and comparing the numbers of ganglionic cells in the myenteric plexus before and after ischemia (GIREI7 $-* p=0.0399$ ). Comparing the percentage of variations in ganglionic cells in the myenteric plexus on the $7^{\text {th }}, 14^{\text {th }}$ and $28^{\text {th }}$ days after the procedure, in the groups GIREI7, GIREI14 and GIREI28, it was observed that there were no significant alterations (KruskalWallis test: $\mathrm{p}=0.6501$-Table $2-$ Figure 2 ). However, It was significant the difference comparing the numbers of ganglionic cells in the myenteric plexus before and after ischemia, (GIREI14 - ${ }^{*} \mathrm{p}=0.0047$ and GIREI28 - *p $=0.0413$ - Wilcoxon test). Immunohistochemical staining of ganglionic cells are showed for Control and Experimental groups in figures 3 and 4, respectively.

TABLE 1 - Immunohistochemical evaluation (protein S-100) of the numbers of ganglionic cells in the myenteric plexus in control group (GCEI7) and experimental group (GCIREI7) both at the $7^{\text {th }}$ post-operative day. It was calculated the variation of the number of the ganglionic cells between pre and post-operative $\operatorname{period}(\Delta \%=[($ Pós-Pré $) /$ Pré $] \times 100)$

\begin{tabular}{lcccccc}
\hline & \multicolumn{3}{c}{ GCEI7 } & \multicolumn{3}{c}{ GIREI7 } \\
\hline & PRE & POST & $\boldsymbol{\Delta} \%$ & PRE & POST & $\mathbf{\Delta} \%$ \\
\hline Rat 1 & 19 & 27 & 42 & 43 & 15 & -65 \\
Rat 2 & 24 & 33 & 38 & 41 & 33 & -20 \\
Rat 3 & 30 & 23 & -23 & 28 & 25 & -11 \\
Rat 4 & 14 & 22 & 57 & 19 & 14 & -26 \\
Rat 5 & 17 & 21 & 24 & 38 & 17 & -55 \\
Rat 6 & 13 & 12 & -8 & 16 & 31 & 94 \\
Rat 7 & 25 & 30 & 20 & 16 & 26 & 63 \\
Rat 8 & 23 & 33 & 43 & 32 & 17 & -47 \\
Rat 9 & 27 & 27 & 0 & 18 & 13 & -28 \\
Rat 10 & 30 & 35 & 17 & 16 & 28 & 75 \\
Rat 11 & 25 & 31 & 24 & 24 & 13 & -46 \\
Rat 12 & 15 & 30 & 100 & 25 & 24 & -4 \\
Rat 13 & 33 & 22 & -33 & 28 & 14 & -50 \\
Rat 14 & 17 & 17 & 0 & 29 & 8 & -72 \\
Rat 15 & 13 & 13 & 0 & 35 & 17 & -51 \\
Rat 16 & 13 & 13 & 0 & 15 & 10 & -33 \\
Rat 17 & 19 & 26 & 37 & 10 & 10 & 0 \\
Rat 18 & 21 & 18 & -14 & 15 & 18 & 20 \\
Rat 19 & 18 & 14 & -22 & 17 & 35 & 106 \\
Rat 20 & 14 & 18 & 29 & 20 & 16 & -20 \\
\hline Mean & $\mathbf{2 0 . 5}$ & $\mathbf{2 3 . 3}$ & $\mathbf{1 6 . 5}$ & $\mathbf{2 4 . 3}$ & $\mathbf{1 9 . 2}$ & $\mathbf{- 8 . 6}$ \\
SD & 6.3 & 7.4 & & 9.6 & 8.0 & \\
\hline
\end{tabular}

SD means standard deviation; GCEI7 means control group (exclusion of a six centimeters intestinal segment); GCIREI7 means experimental group (exclusion of an six centimeters intestinal segment associated to 30 minutes of vascular occlusion)

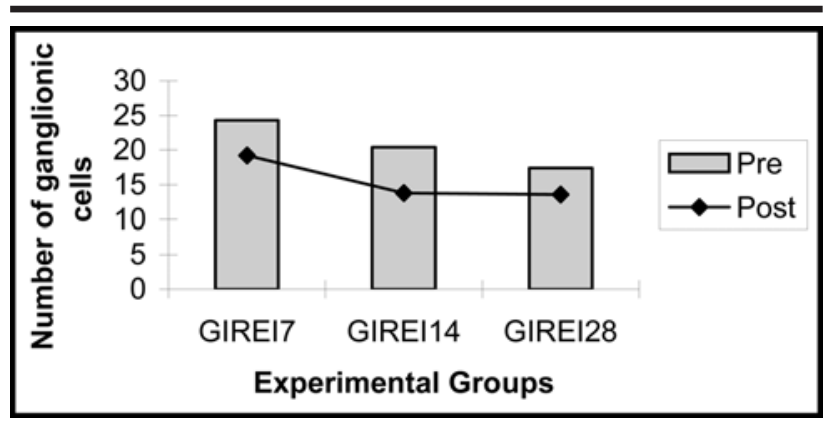

FIGURE 1 - Immunohistochemical evaluation (protein S-100) of the numbers of ganglionic cells in the myenteric plexus in experimental groups (GCIREI7, GCIREI14, and GCIREI28 ) at the $7^{\text {th }}, 14^{\text {th }}$, and $28^{\text {th }}$ post-operative day, respectively. 


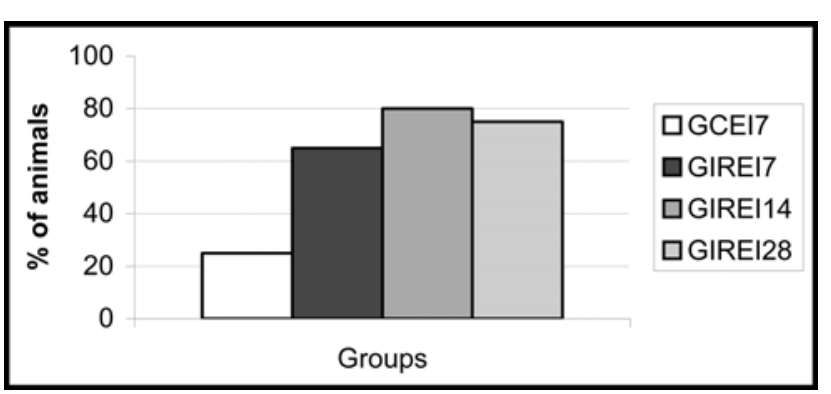

FIGURE 2 - Percentage of animals from all groups (GCEI7, GIREI7, GCIREI14, and GCIREI28), at the 7th, 14th, and 28th postoperative day, respectively, that showed decreased number of ganglionic cells.

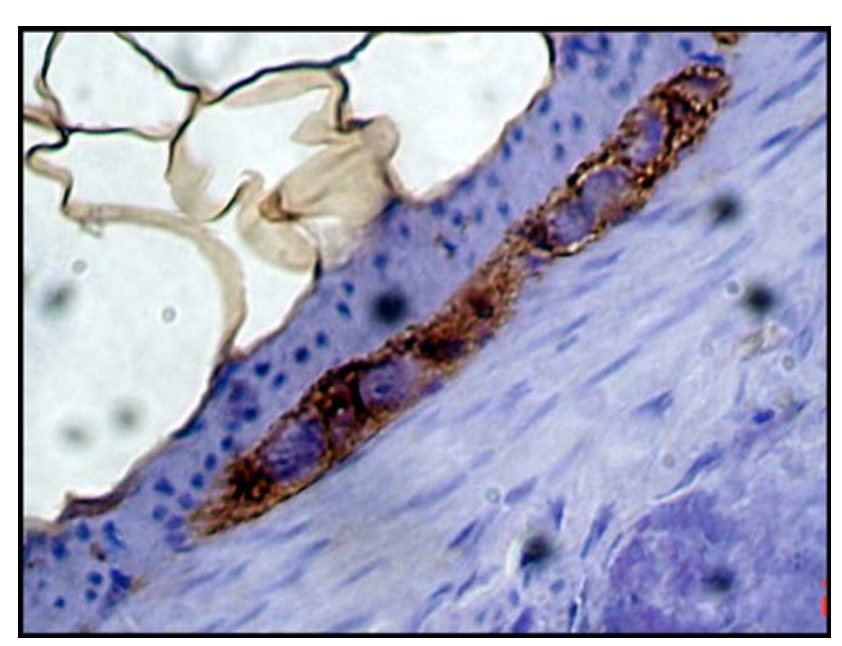

FIGURE 3 - Photomicrograph showing the ganglia stained brown and the ganglionic cells stained violet (negatively), thus displaying the normal appearance of the control group (Protein S$100-400 \mathrm{X})$

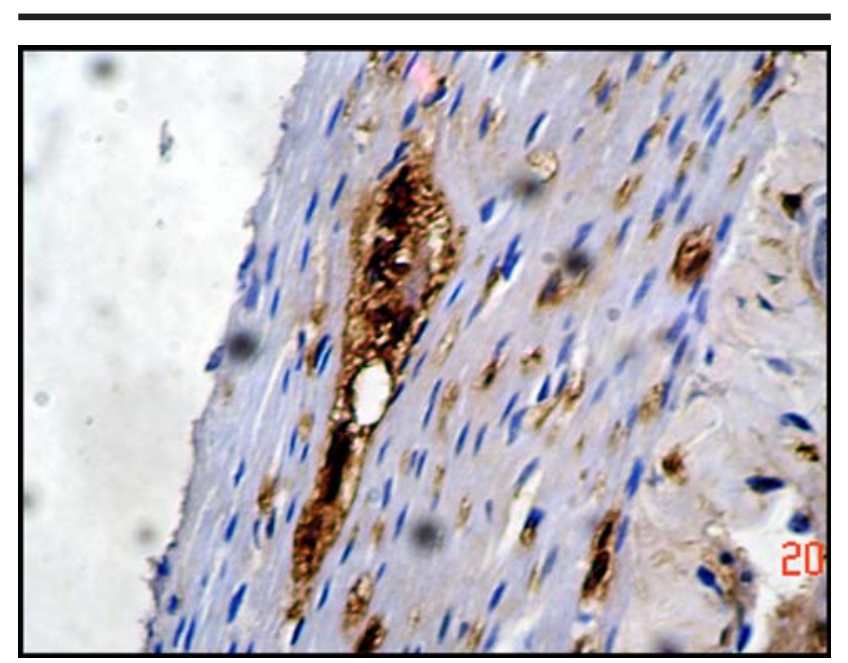

FIGURE 4 - Photomicrograph showing ganglia stained brown and the absence of ganglionic cells in the experimental group (Protein S-100 $400 \mathrm{X})$
TABLE 2 - Variation of the ganglionic cells number between pre and postoperative period was calculated ( $\Delta \%=[($ Pós-Pré)/Pré $] \times 100)$ for all experimental groups (GCIREI7, GCIREI14, and GCIREI28)

\begin{tabular}{lccc}
\hline & \multicolumn{3}{c}{$\Delta \%$} \\
\hline GIREI7 & GIREI14 & GIREI28 \\
\hline Rat 1 & -65 & -41 & 35 \\
Rat 3 & -20 & 0 & -17 \\
Rat 4 & -11 & -50 & -53 \\
Rat 5 & -26 & -56 & -45 \\
Rat 6 & -55 & 74 & -21 \\
Rat 7 & 94 & -78 & -7 \\
Rat 8 & 63 & -13 & -33 \\
Rat 9 & -47 & -39 & -50 \\
Rat 10 & -28 & -78 & 71 \\
Rat 11 & 75 & -50 & 108 \\
Rat 12 & -46 & -15 & -30 \\
Rat 13 & -4 & -83 & -59 \\
Rat 14 & -50 & -45 & -56 \\
Rat 15 & -72 & -29 & -38 \\
Rat 16 & -51 & 200 & -70 \\
Rat 17 & -33 & -30 & -67 \\
Rat 18 & 0 & 6 & -38 \\
Rat 19 & 106 & -18 & 42 \\
Rat 20 & -20 & -24 & 110 \\
\hline Mean & $\mathbf{- 8 . 6}$ & -48 & -48 \\
\hline SD 20 & $-\mathbf{2 0 . 9}$ & $-\mathbf{1 3 . 2}$ \\
\hline
\end{tabular}

SD means standard deviation; GCIREI7, GCIREI14, and GCIREI28 means experimental groups (exclusion of a six centimeters intestinal segment associated to 30 minutes of vascular occlusion )

\section{Discussion}

Ischemic lesions of the intestine may be reversible or irreversible, depending on the length of time for which the tissue has been exposed to hypoxia. We utilized histological analysis since this is the method most utilized for evaluating the degree of tissue lesion caused by the phenomenon of ischemia/reperfusion. When there is a loss of vascularization, there is generally an associated loss of innervation $^{23,24}$. In our experimental model for provoking ischemia/reperfusion, we were able to observe this, especially when comparing the group GCEI7 (control) with the group GIREI7, on the $7^{\text {th }}$ day after undergoing ischemia/ reperfusion. The results indicate to us that the lesions caused by ischemia/reperfusion give rise to decreased numbers of ganglionic cells in the myenteric plexus. This may have the consequence of alterations in intestinal motility, since these cells are essential for transmitting nerve impulses for generating peristaltic movement ${ }^{23,24}$.

\section{Conclusion}

There was a decrease in the number of ganglionic cells in the myenteric plexus due to ischemia and reperfusion that did not recover in the late post-operative period. 


\section{References}

1. Neu J, Weiss MD. Necrotizing enterocolitis: Pathophysiology and prevention. J Parenter Enteral Nutr. 1999; 23:S13-S7.

2. Sigalet DL. Short bowel syndrome in infants and children: an overview. Semin Pediatr Surg. 2001; 10 (2):49-55.

3. Weisteldt ML. Reperfusion and reperfusion injury. Clin Res. 1987; 35(1):13-20.

4. Brito MVH, Araújo M, Araújo GJS, Reis JMC. Lesão intestinal após isquemia - reperfusão: estudo comparativo usando sal tetrazólico (MTT) e histologia. Acta Cir Bras. 2001; 16(1):26-31.

5. Park PO, Gerdin B, Haglund U. Effects of a novel 21 aminosteroid of methylprednisolone in experimental total intestinal ischemia. Arch Surg. 1994; 129: 857-60.

6. Schanaider A, Menezes VJMT, Borchardt AC, Oliveira PL, Madi K. Oxidized tissue proteins after intestinal reperfusion injury in rats. Acta Cir Bras. 2005; 20(6): 434-6.

7. Cuzzocrea S, Riley DP, Caputi AP, Salvemini D. Antioxidant therapy: a new pharmacological approach in shock, inflammation, and ischemia/reperfusion injury. Pharmacol Rev. 2001; 53 (1):135-59.

8. Kazez A, Demirbag M, Ustundag B, Ozercan IH, Saglam M. The role of melatonin in prevention of intestinal ischemiareperfusion injury in rats. J Pediatr Surg. 2000; 35(10):1444-8.

9. Jacob T, Asher E, Hingorani A, Kallakuri S. Glycine prevents the induction of apoptosis attributed to mesenteric ischemia/ reperfusion injury in a rat model. Surgery. 1994; 134:457-66.

10. Furness JB, Costa M. Types of nerves in the enteric nervous system. Neuroscience. 1980; 5:1-20.

11. Meyer KF, Martins JL, Freitas Filho LG, Oliva MLV, Patrício FRS, Macedo M, Wang L. Glycine reduces tissue lipid peroxidation in hypoxia-reoxygenation- induced necrotizing enterocolitis in rats. Acta Cir Bras. 2006; 21(3):161-7.

12. Karaosmanoglu T, Muftuoglu S, Dagdeviren A, Durgun B, Aygun B, Ors U. Morphological changes in the myenteric plexus of rat ileum after transection and end-to-end anastomosis. J Anat. 1996,188 (Pt2): 323-31.

13. Matsumoto T. Injury to myenteric plexus of intestinal segments after vascular pedicle interruption: an experimental study in rats and rabbits. J Nihon Univ Sch Dent. 1997; $39(1): 17-24$.
14. Gerardi Filho VA, Martins JL, Zveibil DK, Novo NF, Juliano Y. Efeito do cloreto de benzalcôneo aplicado sobre o cólon de ratos. Acta Cir Bras. 1999; 14(1):5.

15. Bicakci U, Tander B, Ariturk E, Aydin BK, Aydin O, Rizalar R, Eren Z, Bernay F. Effects of omeprazole and gentamicin on the biochemical and histopathological alterations of the hypoxia/reoxygenation induced intestinal injury in newborn rats. Pediatr Surg Int. 2005; 5:1-6.

16. Meyer KF, Martins JL, Freitas Filho LG, Oliva MLV, Patrício FRS, Macedo M, Wang L. Evaluation of an experimental model of necrotizing enterocolitis in rats. Acta Cir Bras. 2006; 21(2):113-8.

17. Arslan SO, Gelir E, Sayan H, Ozacmak VH. L-Arginine and melatonin interaction in rat intestinal ischemia-reperfusion. Fundam Clin Pharmacol. 2005; 19(5):533-5.

18. Li-Ling, Irving M. The effectiveness of growth hormone, glutamine and a low-fat diet containing high-carbohydrate on the enhancement of the function of remnant intestine among patients with short bowel syndrome: a review of published trials. Clin Nutr. 2001; 20(3):199-204.

19. Taguchi T, Tanaka K, Ikeda K. Immunohistochemical study of neuron-specific enolase and S-100 protein in Hirschsprung's disease. Virchows Arch Pathol Anat. 1985; 405:399-409.

20. Stefanson K, Wollmann RL, Moore BW. Distribution of S100 protein outside the Central Nervous System. Brain Res. 1982; 234:309-17.

21. Rocha MMB, Martins JL, Patricio FRS. Histological and immunohistochemical study of a jejunal segment undergoing neovascularization by omentopexy. Transplant Proc. 2002; 34 990-2.

22. Rocha MMB, Martins JL, Patricio FRS, Tubino P. Are there any structural alterations in a neovascularizated jejunal segment by omentoenteropexy? A histological and immunohistochemistry study. J Pediatr Surg. 2003; 38(8):1141-6 .

23. West KW, Grosfeld JL, Rescoria FJ, Vane DW. Acquired aganglionosis: a rare occurrence following pull-through procedures for Hirschsprung's disease. J Pediatr Surg. 1990; 25(1):104-8.

24. Kobayashi H, Hirakawa H, Surana R, et al. Intestinal neuronal dysplasia is a possible cause of persistent bowel symptoms after pull-through operation for Hirschsprung's diseases. J Pediatr Surg. 1995; 30(2):253-9.

\section{Correspondence:}

José Luiz Martins

Rua dos Otonis, 131

O4025-000 São Paulo - SP Brazil

jlmartins1@terra.com.br
Conflict of interest: none Financial source: none

Received: November 19, 2006

Review: December 14, 2006

Accepted: January 16, 2007

\section{How to cite this article:}

Linhares GK, Martins JL, Fontanezzi F, Patrício FR, Montero EFS. Do lesions of the enteric nervous system occur following intestinal ischemia/reperfusion? Acta Cir Bras. [serial on the Internet] 2007 Mar-Apr;22(2). Available from URL: http://www.scielo.br/acb 